University of New Hampshire

University of New Hampshire Scholars' Repository

\title{
The Changing Spatial Concentration of America's Rural Poor Population
}

\author{
Daniel T. Lichter \\ Cornell University
}

Kenneth M. Johnson

Loyola University Chicago, ken.johnson@unh.edu

Follow this and additional works at: https://scholars.unh.edu/soc_facpub

Part of the Rural Sociology Commons

\section{Recommended Citation}

Lichter, D. T. and Johnson, K. M. (2007), The Changing Spatial Concentration of America's Rural Poor Population. Rural Sociology, 72: 331-358. doi: 10.1526/003601107781799290

This Article is brought to you for free and open access by the Sociology at University of New Hampshire Scholars' Repository. It has been accepted for inclusion in Sociology Scholarship by an authorized administrator of University of New Hampshire Scholars' Repository. For more information, please contact Scholarly.Communication@unh.edu. 


\title{
The Changing Spatial Concentration of America's Rural Poor Population*
}

\author{
Daniel T. Lichter \\ Department of Policy Analysis and Management \\ Cornell University
}

Kenneth M. Johnson

Department of Sociology

Loyola University of Chicago

\begin{abstract}
This paper documents changing patterns of concentrated poverty in nonmetro areas. Data from the Decennial U.S. Census Summary Files show that poverty rates-both overall and for children-declined more rapidly in nonmetro than metro counties in the 1990s. The 1990s also brought large reductions in the number of high-poverty nonmetro counties and declines in the share of rural people, including rural poor people, who were living in them. This suggests that America's rural pockets of poverty may be "drying up" and that spatial inequality in nonmetro America declined over the $1990 \mathrm{~s}$, at least at the county level. On a less optimistic note, concentrated poverty among rural minorities remains exceptionally high. Roughly one-half of all rural blacks and one-third of rural Hispanics live in poor counties. Poor minorities are even more highly concentrated in poor areas. Rural children-especially rural minority children-have poverty rates well above national and nonmetro rates, the concentration of rural minority children is often extreme (i.e., over $80 \%$ lived in high-poverty counties), and the number of nonmetro counties with high levels of persistent child poverty remains high (over 600 counties). Rural poor children may be more disadvantaged than ever, especially if measured by their lack of access to opportunities and divergence with children living elsewhere. Patterns of poverty among rural children-who often grow up to be poor adultssuggest that recent declines in concentrated rural poverty may be short-lived.
\end{abstract}

Debates over welfare reform often pivot on the question of whether reducing caseloads or eliminating poverty should be the primary policy goal. Indeed, the growing public interest in finding solutions to poverty comes at a time when the nation's poverty rates-at least as officially measured-declined rapidly during the late 1990s before inching up

* A version of this paper was presented at the 68th annual meeting of the Rural Sociological Society, Tampa, FL, August 12, 2005. The authors acknowledge the research assistance of Tim Weddle and Rebecca Curtis. Financial support was provided from the North Central Research Station of the U.S. Forest Service to Loyola University and a population center grant (1 R21 HD47943-01) awarded by the National Institute of Child Health and Human Development to the first author and The Ohio State University's Initiative in Population Research. The authors also acknowledge the helpful comments of the editor and two anonymous reviewers. 
again with the early 2001 recession (U.S. Census Bureau 2006). ${ }^{1}$ Still, poverty rates-even in $2005(12.6 \%)$-were significantly lower than in 1993 (over 15\%) when poverty rates were at levels not observed since the 1980s recession and when President Lyndon B. Johnson first declared "war on poverty" in the early 1960s (DeNavas-Walt, Proctor, and Lee 2005). The late 1990s declines in poverty rates presumably resulted from several factors: economic growth that fueled unprecedented job creation and low unemployment (Davis, Connolly, and Weber 2003; Iceland 2003); the expansion of the Earned Income Tax Credit that lifted low-wage workers out of poverty (Lichter and Jensen 2002; Neumark and Wascher 2001); and new welfare reform legislation that emphasized "work first" and placed strict time limits on the receipt of cash public assistance (Corcoran et al. 2000; Lichter, Qian, and Crowley 2005).

Significantly, recent declines in poverty rates were most rapid among historically disadvantaged groups. Rural areas-including isolated populations in Appalachia and in the South-experienced an unexpectedly large drop in poverty in the 1990s (Weber, Duncan, and Whitener 2002). Poverty declines also were especially rapid among racial minorities (including African Americans) and female-headed families with children, both in rural and urban areas (Danziger and Gottschalk 2004; Lichter et al. 2005). In the early 2000s, for example, poverty rates among single mothers, the chief targets of America's welfare reform revolution, were at their lowest levels on public record. ${ }^{2}$ Perhaps more significantly, evidence of highly concentrated urban poverty - the rise of the so-called "underclass" or "ghetto poor" - has given way to new research showing that poverty has become less geographically concentrated in the nation's inner city neighborhoods (Jargowsky 2003; Kingsley and Pettit 2003). Unlike the 1980s, a de-

\footnotetext{
${ }^{1}$ The public's renewed interest in poverty policy is reflected in several ways. For example, with the highest poverty rate in the nation, Louisiana Governor Kathleen Blanco took steps-even before the devastation wrought by Hurricane Katrina-to "turn the tide" on poverty by engaging citizens in developing new solutions that break the cycle of poverty (Jensen 2006a). More recently, the U.S. Congress took up the issue of raising the minimum wage for the first time in more than a decade. In One Nation, Underprivileged: Why American Poverty Affects Us All, Rank (2004) argues that our Judeo-Christian value system requires a strong response to poverty. Indeed, even among the religious right, there seems to be a growing interest in redefining a moral agenda that includes a response to poverty and social injustice.

${ }^{2}$ U.S. poverty rates among female-headed families with children remain very high by contemporary and international standards at about 35.9 percent (Rainwater and Smeeding 2003; U.S. Census Bureau 2006). See Snyder and McLaughlin (2004) for comprehensive analysis of changing poverty rates among female-headed families over the 1980-2000 period.
} 
clining number of metro census tracts exhibited high rates of poverty (e.g., over 20\%). Whether rural poverty has become more or less concentrated over the past decade is less clear.

In this paper, we build on a large urban poverty literature by highlighting changes in the spatial concentration of poverty across America's nonmetro counties during the 1990s. Specifically, our analysis focuses on (1) recent changes in the share of people, including poor people, who live in rural counties with disproportionately poor populations (e.g., over 20 or 30\%) and on (2) the changing population share residing in counties that are persistently poor (i.e., counties with high poverty rates over several decades). As we show in this paper, America's rural population continues to face disproportionately high poverty rates (Cotter 2002; Gundersen 2006; Jensen, Goetz, and Swaminathan 2006), but also has become less geographically concentrated in high-poverty counties over the past decade. The rural poorespecially poor racial minorities-nevertheless remain heavily concentrated in geographically isolated, economically depressed, and often forgotten regions of the country.

\section{Poor People in Impoverished Rural Places}

According to Weber et al. (2005), poverty in America has several distinguishing features. It tends to be spatially concentrated (Voss et al. 2006). It is persistent and seemingly intractable from a policy standpoint-often lasting for several decades (Brown and Warner 1991; Partridge and Rickman 2005). And concentrated and persistent poverty has historically been highest in America's most remote rural areas (see Tickamyer and Duncan 1990; Weinberg 1987). ${ }^{3}$ The rural poverty problem also is more than simply an issue of low family income. Jensen, McLaughlin, and Slack (2003:130) claim that "the poor in poor communities are doubly disadvantaged." The rural poor suffer from low income, but also often endure physical isolation and poor public transportation, inadequate schools, and limited access to medical care and other basic public services (e.g., clean drinking water and modern sewer systems), while institutional support services are frequently limited or simply unavailable (see Brown and Swanson 2003). The rural poor also are more likely to be exposed to environmental toxins (e.g., agricultural chemicals) and work-place injuries. A continuing

\footnotetext{
${ }^{3}$ A recent study by Fisher (2005), however, suggests that rural residence may be endogenous to poverty, i.e., that the higher poverty rate in rural areas may simply reflect the selection of poverty-prone individuals into rural areas rather than a causal effect of rural residence per se.
} 
policy concern is that economic and cultural isolation from America's mainstream may give impetus to a distinctive subculture and maladaptive behaviors (e.g., out-of-wedlock childbearing or welfare dependence) that reinforce the intergenerational cycle of poverty.

With the exception of Appalachia, which is overwhelmingly white in racial composition (Pollard 2004), persistently poor rural counties also are distinguished by heavy concentrations of racial and ethnic minority populations. Poverty rates are exceptionally high, for example, among African Americans in the Mississippi Delta and "Black Belt" crescent (Lee and Singelmann 2005; Parisi et al. 2005), Mexican-origin Hispanics in the colonias of the lower Rio Grande Valley (Saenz 1997; Saenz and Thomas 1991), and Native American Indians living on reservations on the Great Plains. In communities on the Pine Ridge Indian Reservation in South Dakota, poverty rates are often in excess of 50 percent (O'Hare and Johnson 2004). To be sure, disadvantaged racial and immigrant minorities remain heavily concentrated in inner-city neighborhoods of major metro cities, but some of America's most impoverished minorities live in geographically isolated rural areas. Many rural minorities face longstanding traditions of race and class discrimination and economic oppression in their small communities (Albrecht, Albrecht, and Murguia 2005; Duncan 1999; Tomaskovic-Devey and Roscigno 1996).

The apparent "ghettoization" of rural minorities is reflected in the statistical evidence: Over 444 nonmetro counties, or almost 20 percent of all nonmetro counties, had poverty rates of 20 percent or more in 2000 (Beale 2004). Three-fourths of these counties reflect the unique demographic and economic circumstances of racial and ethnic minorities. According to Beale (2004), 210 (47\%) of these high-poverty counties are Black, $74(17 \%)$ are Hispanic, and $40(9 \%)$ counties reflect the low incomes of Native Americans. Minority-defined high-poverty areas are identified when over half of the poor population is a racial minority, or high minority poverty pushes the county's poverty rate over 20 percent (i.e., the white population's poverty rate is less than 20\%). Clearly, discussions and analyses of poverty concentration in rural America cannot be separated from the issue of race.

Most of America's rural high-poverty counties have been poor for several decades (Beale and Gibbs 2006). A recent Economic Research Service (ERS) report estimated that 386 counties have experienced consistently high rates of poverty (over $20 \%$ ) for the last three decades (Jollife 2004). The large majority of these counties are nonmetro (340), and most are located in the South. Moreover, the most isolated and rural populations tend to live in persistently poor counties (Joliffe 2004: Miller and Weber 2003). In 2000, for example, 28 percent of 
people living in completely rural counties (i.e., counties lacking urban places of 2,500 or more population) lived in persistently poor counties. This compares with only 7.5 percent among those who lived in the most urbanized nonmetro counties, i.e., those nonmetro counties with an urban population of 20,000 or more and adjacent to a metro area. To be sure, metro poverty is distributed unevenly at the sub-county level (e.g., between poor inner-city neighborhoods and the suburbs), a situation that is often masked in previous analyses based on countylevel poverty rates (see Brown and Hirschl 1995; Lichter and McLaughlin 1995). On the other hand, a distinguishing feature of nonmetro poverty is that the poor are also seemingly distributed unevenly across larger areal units-counties, multi-county labor market areas, and sub-regions (Lobao 2004; Lyson and Falk 1991).

Although previous studies have clearly highlighted the fact that rural poverty is often geographically concentrated and persistent (Beale and Gibbs 2006; Brown and Warner 1991; Jollife 2004), a key question remains largely unexplored. That is, are more people, more rural people, or more rural poor people actually living in high-poverty or persistently poor rural counties today than in the past? Previous research has typically focused on the number and rate of poverty in high-poverty counties. But if living in poor rural communities has adverse effects on employment, income, education, and health (Albrecht et al. 2005), then it is important to evaluate not only whether the number of poor counties is growing or declining, but to determine whether more people are actually exposed to the putative risks associated with living in poor areas. In fact, persistently poor counties may actually have become poorer over time (if measured by the number of poor as a percentage of population), but the actual size of the resident poor population may have declined. This would occur if the populations of poor counties have contracted through persistent net out-migration or natural decrease (Foulkes and Newbold 2005; Nord, Luloff, and Jensen, 1995; Schafft 2006).

\section{Current Study}

The goal of the current study is to provide an up-to-date and comprehensive portrait of spatial inequality and the changing geographic distribution of America's poor people over the past decade. Our specific analysis contributes in several important ways to our understanding of concentrated and persistent poverty in rural America.

First, our study emphasizes recent changes in the size of the population-both poor and non-poor-residing in the high-poverty 
counties. We also highlight the extraordinarily large racial differences in concentrated poverty in rural areas. As such, our analyses complement recent studies of the changing number and characteristics of "high poverty" or persistent poverty counties.

Second, we also build on the ERS's definition of high-poverty counties by examining the changing number of counties, and the population living in them, with extremely high rates of poverty-those exceeding 30 or 40 percent (Economic Research Service 2005). Previous studies have typically defined high-poverty counties as those with 20 percent or more of the population below the poverty line.

Third, we focus both on the total population and the population of children, including minority children. Rural poverty has an intergenerational dimension (Duncan 1996; Fitchen 1991); poor children today often become tomorrow's poor adults (Lichter et al. 2005; O'Hare and Johnson 2004). It therefore is important to understand whether the current age distribution of the rural poor has built-in momentum for continuing poverty in the future, or if rural poor children today are less heavily concentrated in the poorest counties (because of the outmigration of adults of childbearing age and poor families with children).

Fourth, we calculate inter-county concentration and segregation indices (i.e., the index of dissimilarity) that show whether rural poor people are increasingly melding geographically with the non-poor population. Evidence of declining segregation indices would suggest overall declines in the geographic concentration of the rural poor.

\section{Methods}

\section{Data}

Data for our analysis come from the 1970 through 2000 U.S. Census Summary Files (1, 3, and 4). We consider patterns of poverty across all 3,141 counties in the United States. The independent cities of Virginia are treated as counties. County equivalents, based on minor civil divisions, are used in the New England states (see Johnson and Fuguitt 2000). Counties are classified as metro or nonmetro using the current (2003) metro definition. Nonmetro counties reclassified as metro by 2003 are treated as metro throughout the analysis. ${ }^{4}$ In other words, we

\footnotetext{
${ }^{4}$ A similar practice is used for counties that were metropolitan prior to 2003 but reverted to nonmetropolitan status under the current definition. In all, 2052 counties are categorized as nonmetropolitan using the 2003 classification system and 1089 are categorized as metropolitan. The overall effect of our decision to use the 2003 classification is to significantly reduce the number of counties included in the nonmetropolitan group when compared to research using prior metropolitan definitions.
} 
use a fixed definition of nonmetro counties, a decision rule that insures that change is measured for the same set of nonmetro counties over time. See Fuguitt, Heaton, and Lichter (1988) for a discussion of the substantive implications of adopting fixed or floating definitions of nonmetro counties.

Although conventional, it is a debatable issue whether counties are the most appropriate unit of analysis for the study of concentrated rural poverty. Most metro-level studies of poverty concentration have focused on within-county rather than between-county variation in poverty rates; the emphasis has been on differences in poverty across neighborhoods (Jargowsky 2003; Massey and Denton 1993). Differences in poverty across cities are typically downplayed or ignored altogether. Studies of concentrated rural poverty, on the other hand, have mostly focused on between-county variation in poverty (Lichter and McLaughlin 1995; Voss et al. 2006), often to the neglect of within-county variation in the distribution of poor people. In our analysis, we have chosen counties over census tracts as the unit of analysis for several reasons. First, unlike census tracts, counties have stable boundaries, which allow us to examine changes over time for the same fixed area in 1990 and 2000. Second, unlike census tracts, counties represent salient political units that serve an identifiable population or electorate; the administrative and policy decisions of county political actors (e.g., county commissioners or planners) potentially affect poverty rates overall, not just for particular neighborhoods. Third, the Census Bureau did not identify census tracts for nonmetro counties until 1990, which means that we cannot replicate-at the census tract level-the ERS's typology of persistently poor counties over four census enumerations (1970 through 2000). Although we use counties here as the unit of analysis, we recognize that analyses of metro and nonmetro counties are not strictly comparable, and that trends in between-county poverty concentration may mask patterns at the sub-county level over the 1990s (Jargowsky 2004). ${ }^{5}$

\section{Measurement and Analysis}

Poverty. For our purposes, the poor population includes individuals who fall below the official poverty income line as of the specified census. Specifically, adults and children are defined as poor when they

\footnotetext{
${ }^{5}$ Put concretely, we cannot eliminate the possibility that the geographic scale of significant rural poverty concentration may have shifted over time or that county patterns may mask divergent trends at the sub-county level for some subpopulations (Lichter and Johnson 2006; Lichter et al. 2007). Clearly, such issues are important but await additional analyses.
} 
live in families below the official poverty income thresholds with their specific size and configuration (i.e., adults and children), as determined by the Office of Management and Budget. Family income is measured in the year previous to the year of census enumeration (i.e., 1999 for the 2000 Census). See Fisher and Weber (2004) for discussion of alternative measures of poverty, which show similarly higher poverty rates in nonmetro than metro areas.

High-poverty and persistent poverty counties. In this paper, we examine the distribution and concentration of poverty using a typology that classifies counties based on whether high poverty rates have persisted over an extended period. We use the ERS's measure of persistent poverty (Economic Research Service 2005). ERS defines counties as being persistently poor if 20 percent or more of their populations were living in poverty continuously for the last 30 years (measured by the 1970, 1980, 1990, and 2000 decennial censuses). Using the 2004 classification, there are 386 persistently poor counties in the United States (comprising $12 \%$ of all U.S. counties and $4 \%$ of the U.S. population). Nearly 90 percent (340) of the persistently poor counties are nonmetro counties.

We also use a new measure of persistent child poverty, at the county level, which was developed by Johnson (2005). ${ }^{6}$ Persistent child poverty counties include those in which more than 20 percent of those under the age of 18 have fallen below the poverty line in each of the last four census years. There are 730 counties with persistent child poverty, of which $601(82 \%)$ are located in nonmetro areas. ${ }^{7}$

Analytic approach. Our analysis proceeds in a straightforward fashion. First, we provide an overview of changing rates of poverty in nonmetro and metro areas over the 1980 to 2000 period. Second, we describe spatial differences in the pace of decline in nonmetro county poverty. Specifically, we focus on changes in the number of highpoverty and persistently poor counties and the share of people, including poor people, who live in them. We also show the changing concentration of poor and nonpoor rural people and children over counties using summary measures of spatial inequality (i.e., the index

\footnotetext{
${ }^{6}$ William O'Hare of the Annie E. Casey Foundation provided valuable assistance in the conceptualization of the measure of persistent child poverty. Data on child poverty in 1970, 1980, 1990, and 2000 were compiled by the Economic Research Service of the U.S.D.A. and provided by Tim Parker of ERS.

${ }^{7}$ We use a fixed set of nonmetropolitan counties over the study period. Fortunately, none of the high-poverty counties shifted over time from nonmetropolitan to metropolitan, a situation that would potentially affect the characteristics (including poverty rates) in the nonmetropolitan counties that had remained in our nonmetropolitan universe of counties.
} 
of dissimilarity or so-called "Hoover" index). Third, we disaggregate our analyses by race, which clearly reveals divergent patterns and trends in poverty concentration among whites, African Americans, and Hispanics.

\section{Findings}

\section{Changing Geographic Differentials in Poverty}

We begin by providing an overview of changing poverty rates over the 1980-2000 period. The data in Table 1 provide several straightforward conclusions. For example, the nation's poverty rates-both for the total population and children-declined in the 1990s, reversing a pattern of increasing poverty during the 1980s. Poverty rates also declined in nonmetro areas over the past decade, from 17.3 to 14.8 percent. This compares with only modest reductions in metro counties (12.2 to $11.9 \%)$. Poverty rates were 41 percent higher in nonmetro than metro areas in 1990, but were only 24 percent higher in 2000. The 1990s thus represented a period of metro-nonmetro convergence in poverty rates or declining spatial inequality. ${ }^{8}$ At the same time, any optimism must be balanced with the recognition that nearly 2.3 million nonmetro children were still poor in $2000 .{ }^{9}$ In absolute terms, the child poverty problem is greater than at any other time during the study period considered here.

The bottom panel of Table 1 provides poverty rates for the 386 persistently poor counties (i.e., those with poverty rates of $20 \%$ or higher over the past four censuses). For these counties, poverty ratesboth for the total population and for children-declined during the 1990s. For example, poverty rates overall declined from 31.2 to 26.3 percent. These rates nevertheless remain very high and similar in both metro and nonmetro counties. Over one-third of children in persistently poor counties are poor, a figure that is roughly double the poverty rate for children overall $(16.1 \%)$.

\section{Spatial Inequality and Rural Poverty}

Overview of poverty trends. America's poor population is distributed unevenly over geographic space, which magnifies the social and

\footnotetext{
${ }^{8}$ We also calculated the average poverty rates across all counties as well as metro and nonmetro counties. The average county poverty rate declined from 18.5 to 15.6 percent in nonmetro areas between 1990 and 2000 and from 13.2 to 11.6 percent in metro areas.

${ }^{9}$ Recently release data from the March 2006 Current Population Survey indicate that the number of nonmetropolitan poor children was 2.25 million in 2005 (U.S. Census Bureau 2006).
} 
Table 1. Percent Poor for Total Population and Children by Persistent Poverty and Metro Status, 1980-2000

\begin{tabular}{|c|c|c|c|c|c|c|}
\hline & \multicolumn{3}{|c|}{ Child Poverty } & \multicolumn{3}{|c|}{ Total Poverty } \\
\hline & Total & Metro & Nonmetro & Total & Metro & Nonmetro \\
\hline \multicolumn{7}{|c|}{ All Counties } \\
\hline 2000 & 16.1 & 15.6 & 19.1 & 12.4 & 11.9 & 14.8 \\
\hline 1990 & 17.9 & 16.9 & 22.2 & 13.1 & 12.2 & 17.3 \\
\hline 1980 & 16.0 & 15.2 & 19.2 & 12.4 & 11.6 & 15.9 \\
\hline \multicolumn{7}{|c|}{ Persistent Poverty Counties } \\
\hline 2000 & 34.6 & 34.9 & 34.4 & 26.4 & 26.7 & 26.3 \\
\hline 1990 & 39.9 & 39.6 & 40.0 & 30.7 & 29.8 & 31.2 \\
\hline 1980 & 34.8 & 33.5 & 35.5 & 27.5 & 25.4 & 28.7 \\
\hline
\end{tabular}

Note: Persistent poverty counties had more than $20 \%$ of their population below the poverty line in each census from 1970 to 2000. Typology developed by Economic Research Service of U.S.D.A.. 2003 version used.

Data: U.S. Census Bureau and Economic Research Service, U.S.D.A.

economic impact of poverty on the poor (e.g., poor communities often lack adequate institutional resources, such as schools, clinics, and public services that serve the poor). Figures 1 and 2 map the spatial distribution of overall and child poverty in 2000 (See Friedman and Lichter 1998, and Voss et al. 2006 for parallel analyses of the 1980s and 1990s). First and foremost, they highlight familiar patterns of poverty concentration in Appalachia, the Mississippi Delta, lower Rio Grande River Valley, and on Indian Reservations in the Southwest and Great Plains. More striking, however, is that the two maps, when juxtaposed, clearly reveal the much higher rates of poverty among children than among the rest of population and demonstrate that this pattern is widely dispersed geographically across the United States. The much darker overall shading in Figure 2, especially in the South, provides a window to America's future as these disadvantaged children grow into adulthood.

These children are also more likely to live in persistently poor counties. This is revealed in Figure 3, which provides overlapping distributions of persistently poor counties and counties with persistently high child poverty (i.e., over $20 \%$ for three decades). Overall, 376 counties have overlapping patterns of persistent poverty and persistent child poverty. However, another 354 counties have persistently high rates of child poverty but not persistent overall poverty. Only 10 counties are characterized as having only overall persistent poverty. Clearly, children have disproportionately high rates of poverty, but child poverty also is much more likely than poverty among other age groups to be highly concentrated and persistent over several decades. 


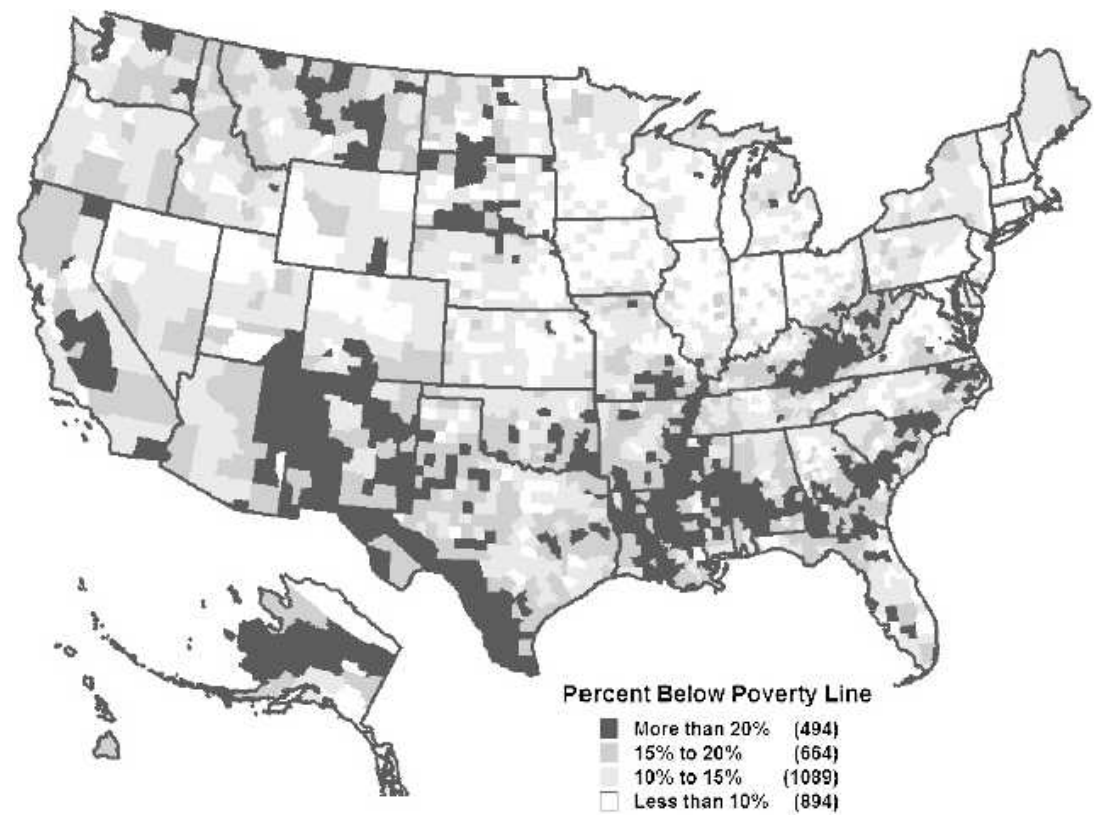

Figure 1. Overall Poverty Rate, 2000

Changing poverty concentration. Poverty rates declined in nonmetro areas over the 1990s, even in persistently poor counties. But are declining shares of America's population (including poor population) residing in high-poverty counties? If so, this would provide counterevidence to speculation of the "ghettoization" and growing spatial inequality in nonmetro America (Lobao 2004). The data in Table 2 shed light on this question. Here, we provide the cumulative percentages of counties and population living in high-poverty and persistently poor counties. In other words, what is the percentage of counties that have poverty rates in excess of $10,20,30,40$, or 50 percent as well as the percentage of people who live in them?

These data support several conclusions. First, for the nation as a whole, as well as for nonmetro and metro counties, the number of counties with very high rates of poverty declined between 1990 and 2000. For example, the number of counties with poverty rates over 20 percent declined nationwide from 852 to 494. This is a substantial reduction over a short 10 -year period. The declines (on a percentage basis) were even larger for counties with extremely high rates of poverty-over 40 percent. In 1990, 52 counties (49 in nonmetro areas) 


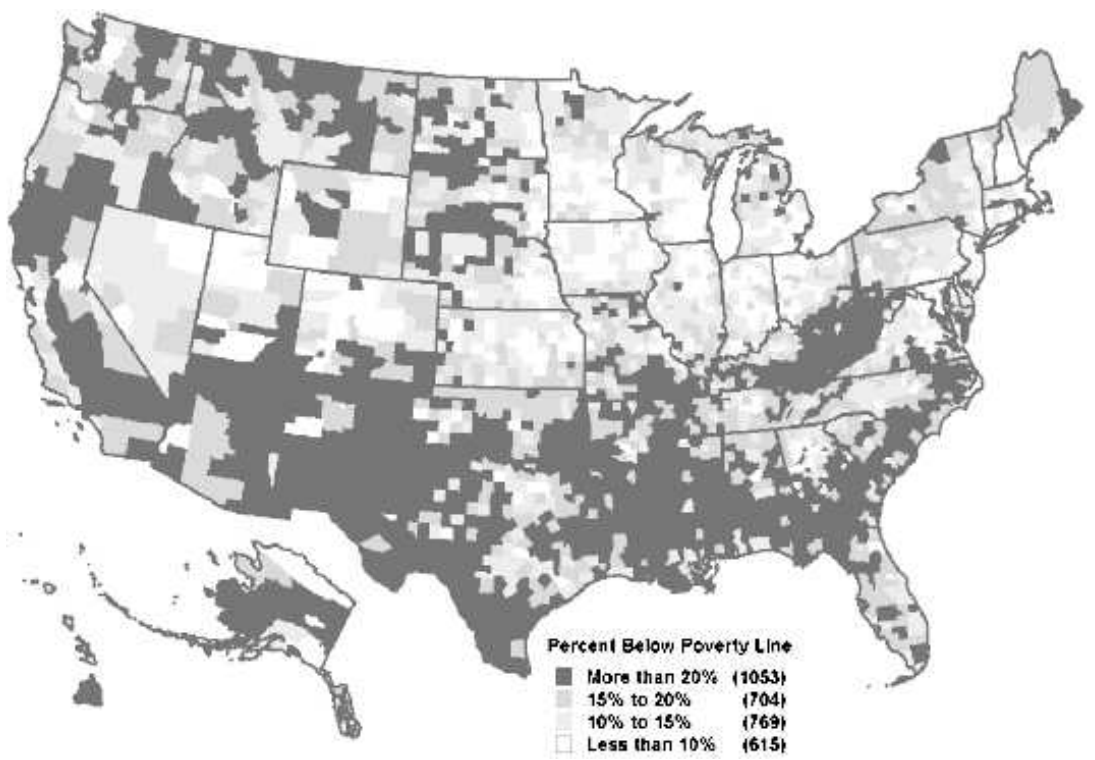

Figure 2. Child Poverty Rate, 2000

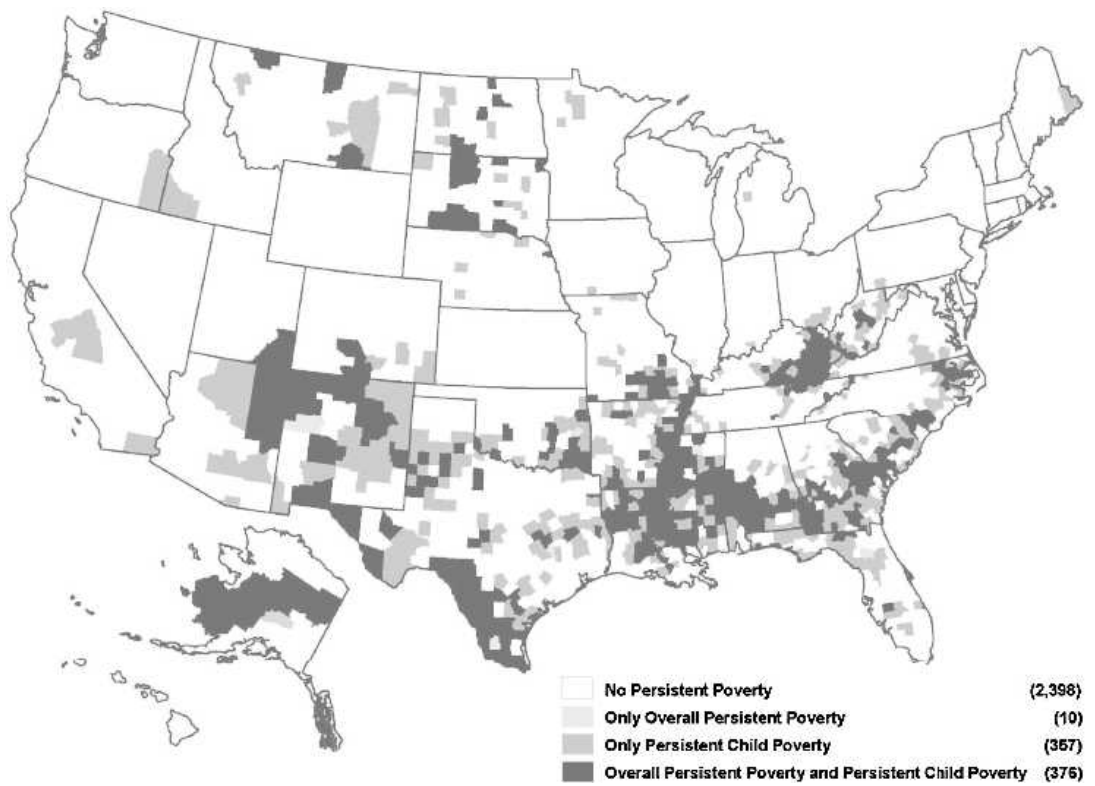

Figure 3. Counties with Overall Persistent Poverty and Persistent Child Poverty 


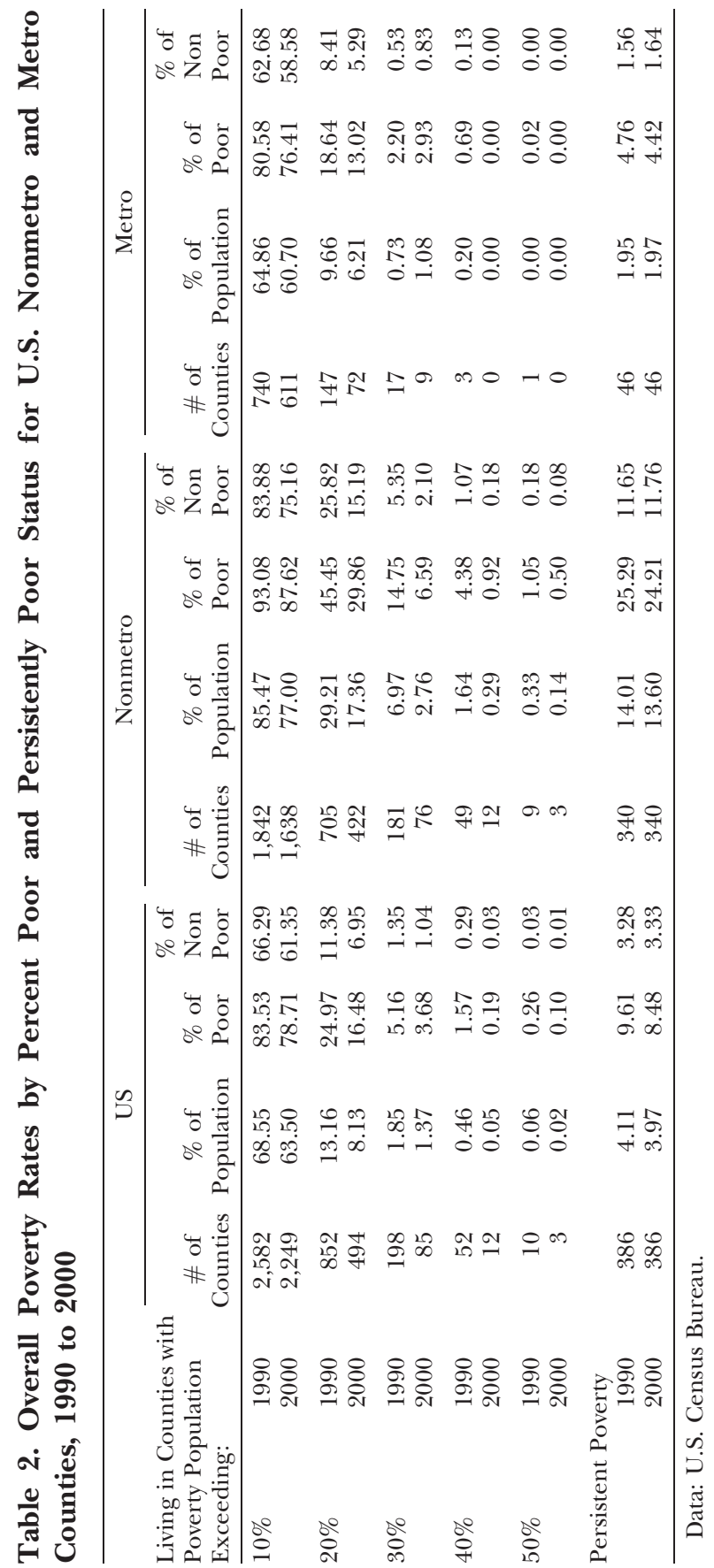


had poverty rates exceeding 40 percent. By 2000, this number had dropped to 12 counties. There is little evidence of rural "ghettoization," if defined as growth in the number of high-poverty counties; in fact, quite the opposite occurred during the 1990s. There has been a withering away of counties with extremely high rates of poverty. ${ }^{10}$

Second, the overwhelming majority of high-poverty counties are in nonmetro areas. Our analysis reveals that 422 of 494 counties (or $85 \%$ ) with poverty rates over 20 percent are nonmetro counties. At the extremes, all 12 of the counties in 2000 with poverty rates exceeding 40 percent were located in nonmetro areas. Of course, we recognize that many inner-city neighborhoods in metro areas also are "poor," often for many decades. Sub-county heterogeneity also may be masked, especially in metro areas, by focusing on county-level poverty. ${ }^{11}$

Third, declining shares of the total nonmetro and metro population, including the poor population, reside in high-poverty counties. For example, 29 percent of the nonmetro population resided in counties with poverty rates of 20 percent or more in 1990. The population living in these counties dropped by 40 percent during the 1990 s, from 29.2 to 17.4 percent. In metro counties, the percentage declined from 9.7 to 6.2 percent (see Table 2). The percentage of poor people living in nonmetro counties declined from 45 to 30 percent (or about onethird), while declining from 19 to 13 percent in metro counties. In counties with extremely high poverty (over 40\%), the share of poor people living in them declined from 4.4 percent in 1990 to 0.9 percent in 2000. Clearly, the rural poor today are much less likely than in 1990 to be spatially concentrated, i.e., living in poor areas.

Fourth, despite evidence of declining poverty concentration in nonmetro areas, it remains the case that nonmetro people, including its poor, are considerably more likely than the nation's population as a whole or those in metro areas to live in high-poverty counties. ${ }^{12}$ For

\footnotetext{
${ }^{10}$ The number of persistently poor counties also declined rapidly over the 1990s, a fact often not fully appreciated unless pre-2000 ERS reports are carefully examined. Indeed, earlier studies published by ERS (Economic Research Service 1995), based on 1960, 1970, 1980, and 1990 census data, showed that there were 535 persistently poor counties. The updated ERS typology, based on the 2000 census (the typology we use here), indicates that there are now 340 persistently poor nonmetropolitan counties. This is a 36 percent drop in the number of persistently poor counties over the 1990s.

${ }^{11}$ According to Beale and Gibbs (2006), only Orleans Parish, LA (New Orleans), and El Paso County, TX, were among metro counties of 400,000 or more people in 2000 that had persistent high poverty.

${ }^{12}$ Obviously, this does not say anything about micro-scale concentration or segregation of the poor within these counties. This question, however, could be addressed with tract level data on the concentration of poor and nonpoor within counties (i.e., neighborhood concentration).
} 
example, in 2000 only about 12 percent of the nonmetro poor lived in counties with very low rates of poverty (i.e., poverty rates under $10 \%$ ). This compares unfavorably with 21 percent of the total population and 24 percent of the metro population. Moreover, whereas nearly 30 percent of the nonmetro poor lived in counties with poverty rates of 20 percent or more, only 16 percent of the overall population and 13 percent of the metro population lived in such counties. These are large differences by almost any measure, yet our understanding of the implications of these patterns for the day-to-day lives of the rural people is unclear. ${ }^{13}$

Table 3 provides parallel analyses of the concentration of children in nonmetro counties with high rates of child poverty. An extensive discussion here is not warranted; suffice it to say that the main conclusions from these analyses overlap significantly with those for the total population (Table 2). It is nevertheless worth pointing out-once again-that poor children in rural areas are likely to be significantly over-represented in high-poverty areas compared with the overall population. For example, more than one-half-56 percent-of poor nonmetro children live in counties with child poverty rates exceeding 20 percent. The corresponding figure for all nonmetro poor people is 30 percent (Table 2). Moreover, one in every 13 nonmetro poor children live in counties with extremely high poverty-over 40 percent, compared with one in every 109 nonmetro poor persons overall.

Summary measures of poverty concentration. To summarize recent evidence of spatial concentration, the Hoover index of population concentration provides empirical evidence of differences in the spatial concentration of poor and nonpoor people over geographic space. ${ }^{14}$

\footnotetext{
${ }^{13}$ These results are certainly consistent with the idea that the low-income populationboth in rural and urban areas-faces many other material disadvantages as a result of their residence patterns (e.g., they live in poor communities that cannot provide proper social services and good schools, say). The poor in these areas are "doubly disadvantaged" (Jensen et al. 2003:130).

${ }^{14}$ The Hoover Index of population concentration that has been widely used in previous research on the spatial concentration of population (Lichter 1985; Long and Nucci 1997; Otterstrom and Shumway 2003). This measure, $H_{t}$, is:

$$
H_{\mathrm{t}}=1 / 2 \sum_{i=1}^{k}\left|p_{i t}-a_{i}\right|
$$

where $p_{i t}$ is the percentage of the (poor) population in county $\mathrm{i}$ at time $\mathrm{t}, \mathrm{a}_{\mathrm{i}}$ is the percent of the nation's land area in county $i$, and $\mathrm{k}$ is the total number of counties. If $p_{i t}$ is equal to $\mathrm{a}_{\mathrm{i}}$ for all counties, then the poverty population is spread over all the counties in proportion to land area, and $H_{t}$ is equal to zero. This would suggest an extremely dispersed pattern of poverty over U.S. counties. The distribution of the poverty population across counties becomes increasingly concentrated as $\mathrm{H}_{\mathrm{t}}$ approaches 100 .
} 
346 Rural Sociology, Vol. 72, No. 3, September 2007

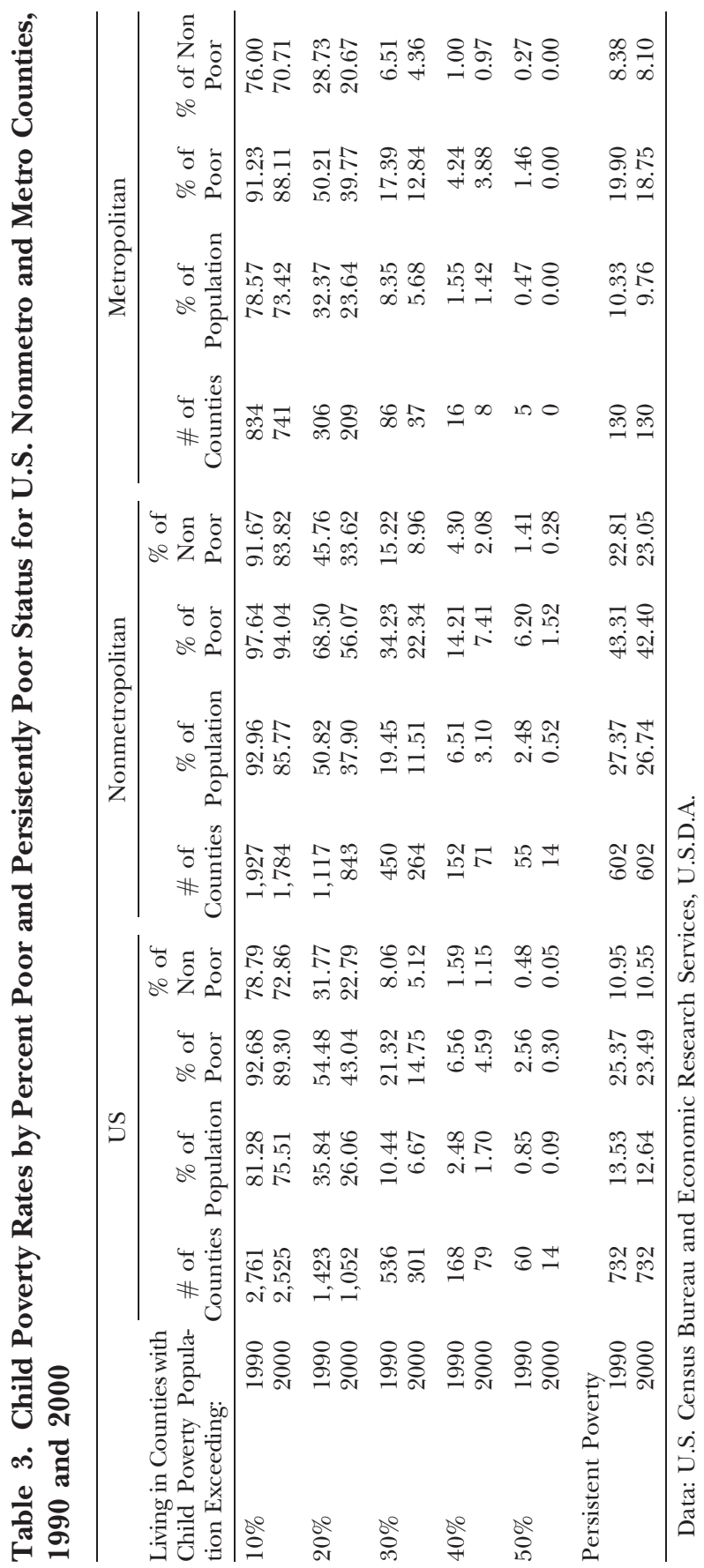


These data, reported in Table 4, show that the poor and non-poor populations (both the total and child population) are distributed remarkably similarly over U.S. counties. Nationally, 60.5 percent of the poor and 63.5 percent of the non-poor would have to move to another county in order for population density to be equal in each county (i.e., population was distributed proportional to land area). At the same time, there also is some evidence that the geographic concentration of the poor has increased slightly over the 1990s, for both the total population and children, and in metro and nonmetro areas. The reverse pattern occurred among the nonpoor population, which became slightly more dispersed by 2000 . Nevertheless, the fact that the Hoover index is generally lower for the poor than the nonpoor nationally is consistent with previous evidence that poverty rates have tended to be lower overall in metro than nonmetro counties, especially remote nonmetro areas (Joliffe 2004).

Whether the poor are physically concentrated in one location may be less relevant than whether they are separated spatially from the nonpoor. So-called "concentration effects" (i.e., effects of concentrated or neighborhood or regional poverty) on various outcomes (e.g., employment, out-of-wedlock childbearing, and welfare dependence) can result directly from the lack of exposure to the cultural and economic mainstream of society (Furstenberg and Hughes 1997; see review volumes by Duncan, Brooks-Gunn, and Aber 1997). ${ }^{15}$ Racial concentration seems to have especially strong negative effects on black attainment and racial inequality, especially in the South (Albrecht et al. 2005; Tomaskovic-Devey and Roscigno 1996). In short, a common assumption is that poor people in poor places may lack sufficient opportunities or the institutional supports necessary to succeed. ${ }^{16}$

To address this question, we evaluate patterns of residential segregation of the poor and non-poor populations. The most common measure of segregation is the index of dissimilarity or segregation index (Frey and Farley 1996; Massey, White, and Phua 1996). The index of dissimilarity, $D_{t}$, measures the uneven spread of two populations over

\footnotetext{
${ }^{15}$ Concentration or neighborhood effects are typically smaller in magnitude than the effects of family structure and income on child outcomes (Ginther, Haveman, and Wolfe 2000).

${ }^{16}$ This is a common argument used to explain persistent racial inequality in United States. Blacks are highly segregated residentially, lack access to middle-class cultural values and behaviors, and are denied access to good jobs elsewhere in the city (Massey and Denton 1993).
} 
Table 4. Hoover Index of Population Concentration for Poverty and Non-Poverty by Metro Status, 1990 and 2000

\begin{tabular}{|c|c|c|c|c|c|c|}
\hline \multirow[b]{2}{*}{$\begin{array}{l}\text { Census } \\
\text { Year }\end{array}$} & \multicolumn{3}{|c|}{ Total Population } & \multicolumn{3}{|c|}{ Child Population } \\
\hline & $\begin{array}{c}\text { USA } \\
\text { (Lower 48) }\end{array}$ & Metro & Nonmetro & $\begin{array}{c}\text { USA } \\
\text { (Lower 48) }\end{array}$ & Metro & Nonmetro \\
\hline \multicolumn{7}{|l|}{ Total Population } \\
\hline 2000 & 62.85 & 52.33 & 47.36 & 62.66 & 51.69 & 46.55 \\
\hline 1990 & 62.69 & 53.64 & 47.28 & 61.32 & 52.08 & 46.29 \\
\hline \multicolumn{7}{|l|}{ Poor } \\
\hline 2000 & 60.48 & 53.00 & 47.29 & 61.09 & 53.69 & 47.33 \\
\hline 1990 & 58.21 & 52.80 & 47.01 & 58.79 & 53.41 & 46.89 \\
\hline \multicolumn{7}{|l|}{ Non-Poor } \\
\hline 2000 & 63.49 & 52.52 & 47.77 & 63.44 & 51.89 & 47.16 \\
\hline 1990 & 63.71 & 54.09 & 47.87 & 62.49 & 52.33 & 47.02 \\
\hline
\end{tabular}

Data: U.S. Census Bureau.

geographic space (i.e., neighborhood, counties, and metro areas). ${ }^{17}$ The data in Table 5 reinforce the conclusion regarding the changing concentration of poverty nationwide and in nonmetro areas. For example, nationally, the index of dissimilarity declined slightly from 20.53 to 19.47 -about 5 percent-between 1990 and 2000. These results have a straightforward interpretation: About 20 percent of the U.S. poor population would need to move to another county in order to achieve similar percentages of poor and non-poor people across all U.S. counties. To put these figures in perspective, racial neighborhood segregation indexes in large cities are typically above 50 in the United States, and inter-county black-white segregation is over 40 (Lichter and Johnson 2006; Wilkes and Iceland 2004).

Our results also indicate that any differences in the spatial segregation of the poor (at least at the county level) are small between metro and nonmetro areas (Table 5). However, declines in the 1990s were more pronounced in nonmetro areas-declining by 1.2 percentage points, compared with 0.6 percentage points in metro areas. As with

${ }^{17}$ The index of dissimilarity, $D_{\mathrm{t}}$, is defined as:

$$
D_{\mathrm{t}}=1 / 2 \sum_{i=1}^{k}\left|p_{i t}-n_{i t}\right|
$$

where $p_{i t}$ and $\mathrm{w}_{i t}$ are the respective percentages of poor (either for children or the overall population) and nonpoor residing in county $i$ at time $t$. If the poor population percentage $\left(p_{i t}\right)$ and nonpoor percentage $\left(\mathrm{n}_{i t}\right)$ are equal in all $\mathrm{k}$ counties, then $D_{\mathrm{t}}$ is equal to 0 , meaning that the poor and nonpoor are distributed in the same percentages over counties, and residential segregation is low. Conversely, a $D_{t}$ of 100 means complete poverty segregation; 100 percent of the nation's poor population would have to move to other counties before the poor/nonpoor distribution across counties would be equal. 
Table 5. Segregation Index for Poor Population and Poor Children by Metro Status and Region, 1990 and 2000

\begin{tabular}{|c|c|c|c|c|c|c|c|}
\hline Population & Year & $\begin{array}{c}\text { USA } \\
\text { (Lower 48) }\end{array}$ & West & Midwest & Northeast & South & $\begin{array}{r}\text { Alaska/ } \\
\text { Hawaii }\end{array}$ \\
\hline \multicolumn{8}{|l|}{ Segregation of Poor } \\
\hline All Counties & $\begin{array}{l}1990 \\
2000\end{array}$ & $\begin{array}{l}20.53 \\
19.47\end{array}$ & $\begin{array}{l}15.00 \\
16.48\end{array}$ & $\begin{array}{l}17.18 \\
17.72\end{array}$ & $\begin{array}{l}23.74 \\
23.30\end{array}$ & $\begin{array}{l}20.85 \\
18.60\end{array}$ & $\begin{array}{r}12.69 \\
9.33\end{array}$ \\
\hline Metro Counties & $\begin{array}{l}1900 \\
2000\end{array}$ & $\begin{array}{l}19.80 \\
19.20\end{array}$ & $\begin{array}{l}14.09 \\
16.24\end{array}$ & $\begin{array}{l}17.82 \\
18.52\end{array}$ & $\begin{array}{l}24.77 \\
24.43\end{array}$ & $\begin{array}{l}19.46 \\
17.68\end{array}$ & $\begin{array}{l}1.13 \\
5.87\end{array}$ \\
\hline $\begin{array}{l}\text { Nonmetro } \\
\text { Counties }\end{array}$ & $\begin{array}{l}1900 \\
2000\end{array}$ & $\begin{array}{l}20.53 \\
19.29\end{array}$ & $\begin{array}{l}17.62 \\
16.89\end{array}$ & $\begin{array}{l}15.94 \\
15.77\end{array}$ & $\begin{array}{l}13.42 \\
12.86\end{array}$ & $\begin{array}{l}17.76 \\
16.01\end{array}$ & $\begin{array}{l}24.10 \\
16.27\end{array}$ \\
\hline $\begin{array}{l}\text { Segregation of Poor } \mathrm{Cl} \\
\text { All Counties }\end{array}$ & $\begin{array}{l}\text { hildren } \\
1990 \\
2000\end{array}$ & $\begin{array}{l}23.18 \\
25.71\end{array}$ & $\begin{array}{l}17.68 \\
19.48\end{array}$ & $\begin{array}{l}21.73 \\
24.30\end{array}$ & $\begin{array}{l}27.72 \\
29.96\end{array}$ & $\begin{array}{l}22.39 \\
26.86\end{array}$ & $\begin{array}{l}14.89 \\
14.32\end{array}$ \\
\hline Metro Counties & $\begin{array}{l}1900 \\
2000\end{array}$ & $\begin{array}{l}22.72 \\
25.12\end{array}$ & $\begin{array}{l}16.94 \\
18.40\end{array}$ & $\begin{array}{l}23.11 \\
26.09\end{array}$ & $\begin{array}{l}29.19 \\
31.04\end{array}$ & $\begin{array}{l}21.01 \\
24.87\end{array}$ & $\begin{array}{l}3.10 \\
6.12\end{array}$ \\
\hline Nonmetro Counties & $\begin{array}{l}1900 \\
2000\end{array}$ & $\begin{array}{l}23.34 \\
24.79\end{array}$ & $\begin{array}{l}20.04 \\
21.07\end{array}$ & $\begin{array}{l}18.32 \\
19.26\end{array}$ & $\begin{array}{l}15.50 \\
18.32\end{array}$ & $\begin{array}{l}20.30 \\
24.67\end{array}$ & $\begin{array}{l}29.10 \\
28.35\end{array}$ \\
\hline
\end{tabular}

Data: U.S. Census Bureau and Economic Research Service, U.S.D.A.

the detailed analyses in Tables 2 and 3, the index of dissimilarity reinforces the point that poverty concentration or segregation is more pronounced among America's children than in its overall population. And, perhaps more significantly, the data indicate that the separation of poor children from non-poor children increased nationwide during the 1990s-from 23.18 to 25.71. Whether this shift is of sufficient magnitude to heighten "concentration effects" on children is unclear.

\section{Racial Differences in Concentrated Poverty}

America's rural pockets of poverty, with the exception of Appalachia, tend to be disproportionately comprised of minorities: Blacks in the rural South, Native American Indians living on reservations in the Dakotas or Southwest, and Hispanics along the Rio Grande Valley and in the border states. These areas represent concentrated rural poverty at its most extreme. As shown in Table 6, nearly all nonmetro blacks $(96.7 \%)$ lived in counties with poverty rates greater than 10 percent in 2000. This compares with 74 percent among non-Hispanic whites. These are large differences by any definition.

Perhaps more significantly, one-half $(50.3 \%)$ of all rural blacks and 58.2 percent of poor rural blacks lived in high-poverty counties of 20 percent or more in 2000. Clearly, rural blacks-poor and non-poortypically live in poor counties. Any disadvantages they experience from poverty are compounded by living in high-poverty areas, which typically 


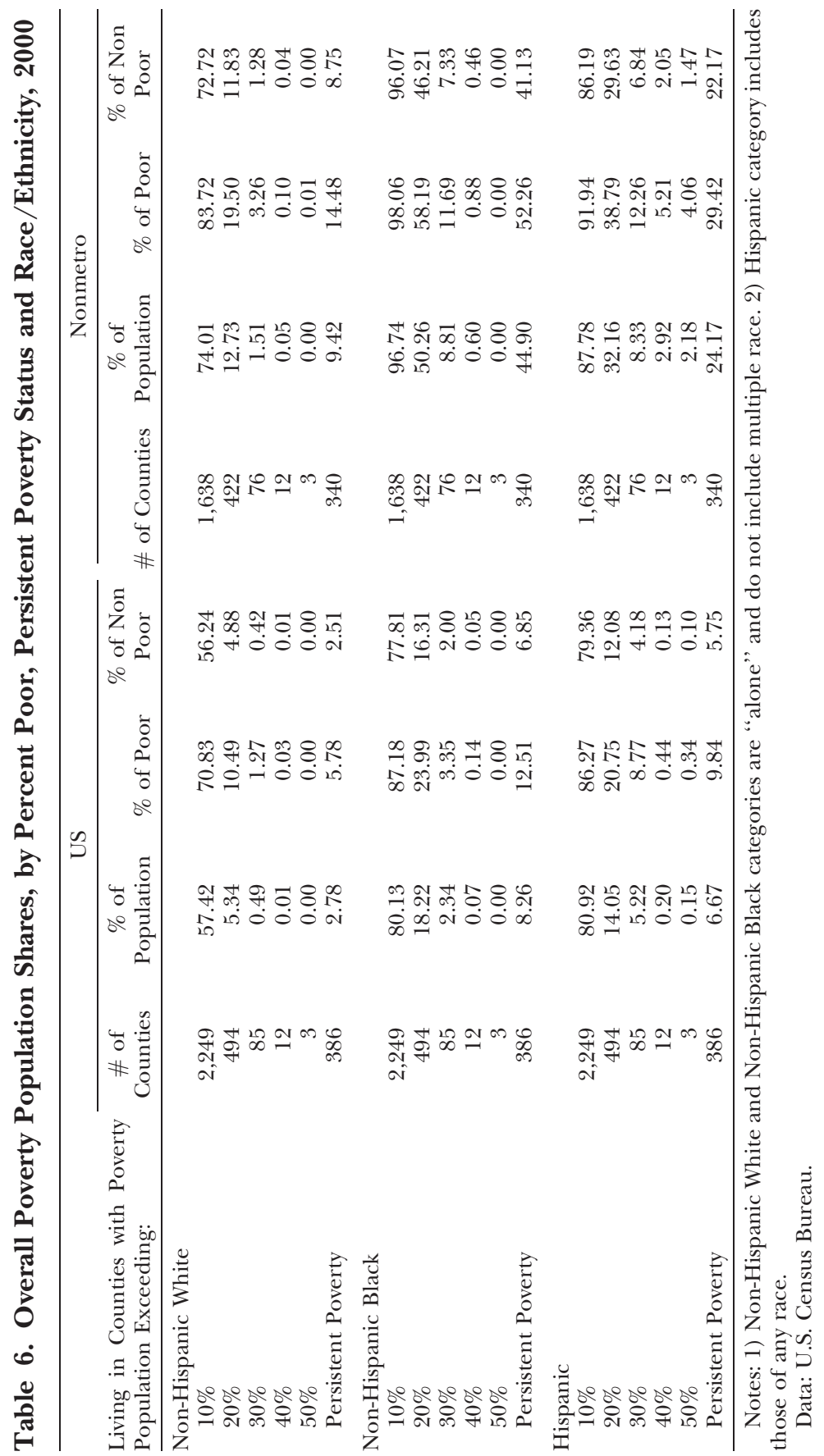


have fewer good jobs, educational opportunities, and public services and infrastructure. These figures for rural areas contrast sharply with the situation for blacks nationally, where only about 18 percent live in high-poverty counties (with poverty rates of $20 \%$ or more), and with the situation for rural poor whites, where only about 20 percent live in counties with poverty rates exceeding 20 percent. Moreover, whereas 52.3 percent of rural poor blacks lived in persistently poor counties, only 14.5 percent of poor rural whites lived in these counties, and only 12.5 percent of all poor blacks nationally.

For Hispanics, the situation is much the same. Although concentrated poverty is less extreme for rural Hispanics-poor or nonpoor-than for rural blacks, poverty is nevertheless heavily concentrated in comparison to patterns of rural whites. Nearly 40 percent of rural poor Hispanics lived in counties with poverty rates exceeding 20 percent in 2000, which compares unfavorably with the 20.8 percent of all Hispanics nationally and is roughly double the figure observed for poor rural whites.

Although rural poor and nonpoor Hispanics are less likely to live in poor counties than are rural blacks, it nevertheless is the case that a higher percentage of the Hispanic poor live in counties with extremely high rates of poverty-over 40 or even 50 percent. In 2000, 5.2 percent of rural poor Hispanics lived in counties with poverty rates exceeding 40 percent; many of these are located along the lower Rio Grande River on the Mexico-U.S. border (e.g., Starr County, Texas). The corresponding number for blacks is less than 1 percent $(0.9 \%)$. Stated differently, this means that a higher percentage of poor rural Hispanics than poor rural blacks live the nation's most economically depressed regions. Still, rural Hispanics are much less likely than their black counterparts to live in persistently poor counties (24 vs. $45 \%$ ). The spread of Hispanics-including both documented and undocumented immigrants-to new destinations in the Midwest and South may partially account for recent trends in concentrated poverty. Poverty rates among Mexican-American families with children in new rural destinations are lower than rates observed in traditional gateway communities in the Southwest (Crowley, Lichter, and Qian 2006; Jensen 2006b).

Table 7 provides parallel analyses of poverty concentration among poor and non-poor minority children. These results suggest several conclusions. First, racial differentials in poverty concentration among children parallel patterns founds for the entire population (see Table 6). The overwhelming share of rural poor black children-83 percent-live in poor counties (defined as 20\% or more of poor 


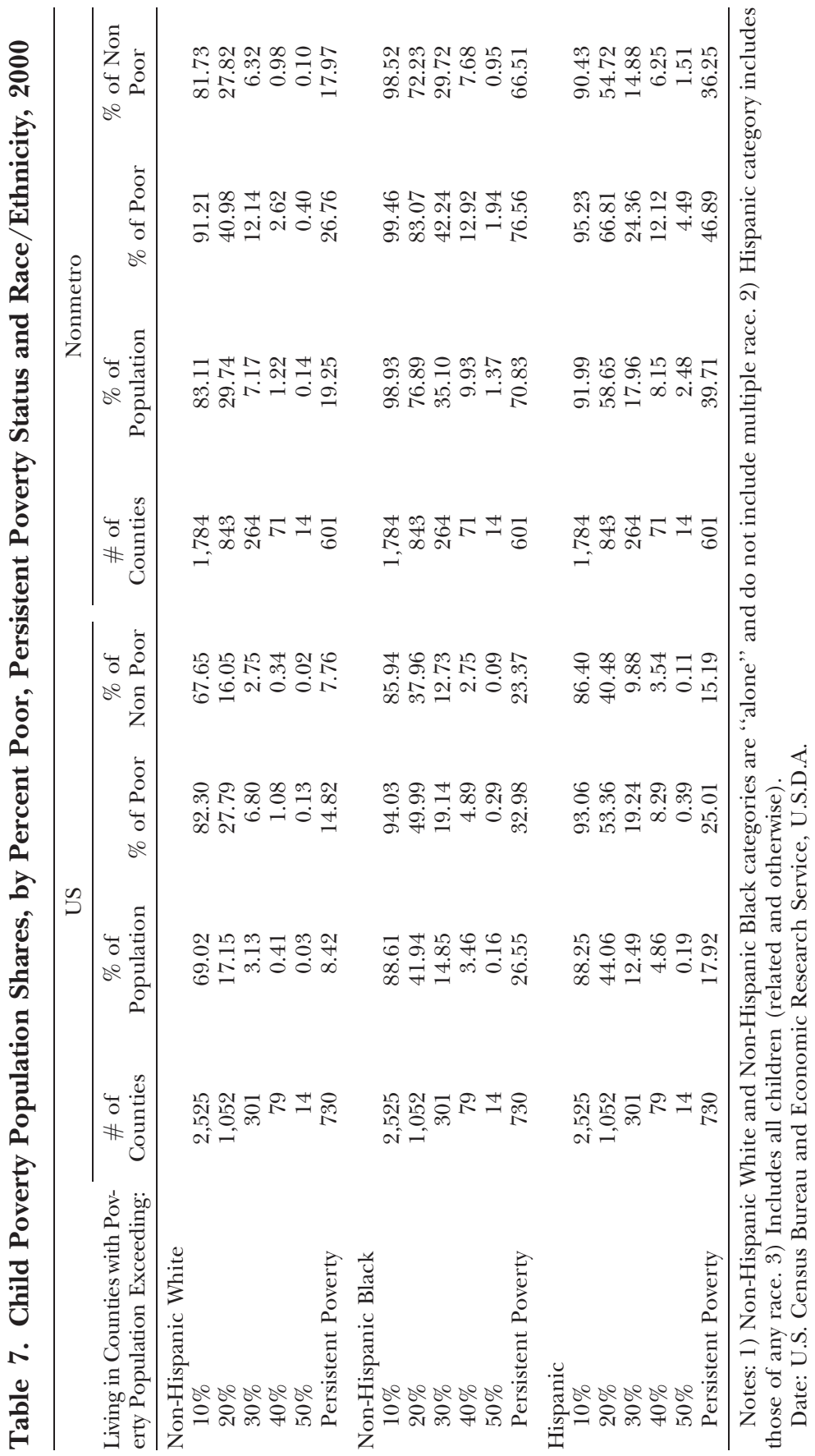


children), compared with 67 percent and 41 percent among their Hispanic and white counterparts, respectively.

Second, rural poor minority children are overrepresented among the minority poor living in poor counties; i.e., poor minority children are disproportionately concentrated in poor rural areas (compare Tables 6 and 7). These differences are large: 42 percent of poor rural black children live in counties with poverty rates of 30 percent or greater, compared with about 12 percent of all rural poor blacks. For Hispanic poor children, 18 percent live in counties with poverty rates over 30 percent, compared with about 12 percent among the rural Hispanic population overall.

Third, a disproportionately large percentage of poor minority children in rural areas lived in persistently poor counties. Whereas only about 13 percent of all poor blacks nationally lived in persistently poor counties in 2000, 77 percent of all rural poor black children lived in such areas. The comparable figures for Hispanics are 10 and 47 percent. The level of poverty concentration among poor rural minority is extreme, even in comparison to other minorities. The substantive implication is that rural poor minority children are highly ghettoized in rural America. They undoubtedly are exposed to environmental circumstances (e.g., poor local economic conditions, inadequate human services, poor schools, and nonworking adult role models) that are far out of the American mainstream. ${ }^{18}$ Poor children living in poor communities are doubly jeopardized (Evans 2004), and, as we have shown here, minority poor children in rural areas are especially "at risk."

\section{Discussion and Conclusion}

A growing literature has documented the extent and social implications of concentrated poverty in the United States, especially in inner-city neighborhoods of major metro cities (Blank 2005; Duncan, BrooksGunn, and Aber 1997; Jargowsky and Yang 2006). There has been much less systematic attention given to issues of concentrated poverty in nonmetro areas (Albrecht et al. 2005; Fossett and Seibert 1997). We do know from previous research, however, that nonmetro poverty historically has tended to be both spatially concentrated and persistent

\footnotetext{
${ }^{18}$ In some additional analysis (data not shown) of nonmetro counties with persistently high rates of child poverty, 46 percent of households in these counties had incomes of less than $\$ 25,000$ annually, compared with only 34 percent in all other counties. Moreover, nearly one-third of the adults in these counties were high school dropouts, compared with about 20 percent among other counties.
} 
in geographically and culturally distinct regions of the country (Beale and Gibbs 2006), regions that overlap significantly with heavy concentrations of rural minority population (e.g., blacks in the Mississippi Delta or Mexican-Americans and immigrants in the Rio Grande River valley on the Mexico-U.S. border). But we lack convincing evidence concerning whether the poor are becoming increasingly concentrated in these areas or regions, i.e., whether the rural poor are more isolated geographically than in the past from mainstream society. Our study has addressed this question with data from the 1990 and 2000 decennial censuses.

Our empirical results indicated that the 1990s marked a significant departure along several spatial dimensions of rural poverty. First and foremost, nonmetro poverty rates-both the total and for childrendeclined more rapidly than metro rates in the 1990s. The 1990s also brought large reductions in the number of high-poverty and persistently poor nonmetro counties and declines in the share of rural people, including rural poor people, who were living in them. In particular, the number of extremely poor counties (i.e., over $40 \%$ ) and the percentage of rural people living in them declined dramatically over the most recent decade. Clearly, these changing redistribution patterns among the poor imply a "drying up" of some of America's rural pockets of poverty-at least as they have been defined in the past at the county level (e.g., Beale and Gibbs 2006) — rather than provide evidence of accelerated spatial inequality in nonmetro America.

On a less optimistic note, our results also may suggest that the recent transformation of concentrated rural poverty may be short-lived. Rural children, especially racial minorities, have poverty rates well above national and nonmetro rates. And the number of nonmetro counties with high levels of child poverty that persist over several decades is much higher than the number of persistent poverty counties overall. This is an important demographic disparity, especially if "concentration" effects prey disproportionately on children and adolescents as they make their way to adulthood and productive adult roles. One implication of our results is that rural children-those still in persistent poor counties-may be more disadvantaged than ever, if we measure disadvantage by the lack of opportunities and community resources that can promote positive development. In a word, their circumstances may be diverging rapidly from those of America's middle-class children (see McLanahan 2005). For poor rural black children, over 80 percent lived in high-poverty counties; two-thirds of poor Hispanic children in 2000 lived in counties with poverty rates exceeding 20 percent. Clearly, the harsh residential circumstances of rural minority children- 
especially the poor-jeopardize the likelihood of a successful and productive adulthood.

In the final analyses, our study provides new evidence of declining spatial inequality in rural America. But, for some population groupsespecially rural children and minorities-poverty concentration is substantial. Moreover, we cannot determine with our county-level data whether declining concentration of rural poverty is simply masking increasing concentration at the micro-scale level, a pattern of nucleated settlement of the poor within counties. Our results cannot speak to the question of whether the poor and non-poor have exhibited similar or divergent residence patterns within poor or persistently poor counties, or, for that matter, even within other non-poor counties. Indeed, studies of population deconcentration within specific major metro cities provide a cautionary lesson (Wilkes and Iceland 2004); suburbanization and exurban growth is highly selective of the most affluent segments of society. Evidence of unprecedented declines in the concentration of rural poor across poor counties represents only a first step to greater understanding of changing poverty concentration across nonmetro America. We cannot discount the possibility-even likelihood-that the geographic scale of significant rural ghettoization has simply been redefined to the micro-scale level or that aggregate county patterns mask patterns for other important population subgroups (Brown and Lichter 2004; Snyder, McLaughlin, and Findeis 2006).

\section{References}

Albrecht, D.E., C. Albrecht, and E. Murguia. 2005. "Minority Concentration, Disadvantage, and Inequality in the Nonmetropolitan United States." Sociological Quarterly 46:503-23.

Beale, C.L. 2004. "Anatomy of Nonmetro High-Poverty Areas: Common in Plight, Distinctive in Nature." Amber Waves 3(February):21-27.

Beale, C.L. and R.M. Gibbs. 2006. "Severity and Concentration of Persistent High Poverty in Nonmetro Areas." Amber Waves 4(1):10-11.

Blank, R.M. 2005. "Poverty, Policy and Place: How Poverty and Policies to Alleviate Poverty are Shaped by Local Characteristics." International Regional Science Review 28:441-64.

Brown, D.L. and T.A. Hirschl. 1995. "Household Poverty in Rural and Metropolitan-Core Areas of the United States." Rural Sociology 60:44-66.

Brown, D.L. and L.E. Swanson. 2003. Challenges for Rural America in the Twenty-First Century. University Park, PA: Penn State University Press.

Brown, D.L. and M.E. Warner. 1991. "Persistent Low-Income Nonmetropolitan Areas in the United States: Some Conceptual Challenges for Development Policy.' Policy Studies Journal 19:22-41.

Brown, J.B. and D.T. Lichter. 2004. "Poverty, Welfare, and the Livelihood Strategies of Nonmetropolitan Single Mothers.” Rural Sociology 69:282-301.

Corcoran, M., S.K. Danziger, A. Kalil, and K.S. Seefeldt. 2000. "How Welfare Reform is Affecting Women's Work." Annual Review of Sociology 26:241-69.

Cotter, D.A. 2002. "Poor People in Poor Places: Local Opportunity Structures and Household Poverty." Rural Sociology 67:534-55. 
Crowley, M., D.T. Lichter, and Z. Qian. 2006. “Beyond Gateway Cities: Economic Restructuring and Poverty among Mexican Immigrant Families and Children.' Family Relations 55:345-60.

Danziger, S. and P. Gottschalk. 2004. Diverging Fortunes: Trends in Poverty and Inequality. The America People Series. Washington, DC and New York: Population Reference Bureau and Russell Sage Foundation.

Davis, E.E., L.S. Connolly, and B.A. Weber. 2003. "Local Labor Market Conditions and the Jobless Poor: How Much Does Local Job Growth Help in Rural Areas?” Journal of Agricultural and Resource Economics 28:503-18.

DeNavos-Walt, C., B.D. Proctor, and C.H. Lee. 2005. Income, Poverty, and Health Insurance Coverage in the United States: 2004. Current Population Reports. P60-229. Washington DC: U.S. Government Printing Office.

Duncan, C.M. 1996. "Understanding Persistent Poverty: Social Class Context in Rural Communities." Rural Sociology 61:103-24.

- 1999. Worlds Apart: Why Poverty Persists in Rural America. New Haven, CT: Yale University Press.

Duncan, G., J. Brooks-Gunn, and J.L. Aber. 1997. Neighborhood Poverty: Context and Consequences for Children. Vol. I and II. New York: Russell Sage Foundation.

Economic Research Service. 1995. Understanding Rural America. Agriculture Information Bulletin No. 710. Washington, DC: U.S. Department of Agriculture.

- 2005. Measuring Rurality: 2004 County Typology Codes. (MRDF). Washington, D.C.: U.S. Department of Agriculture. Retrieved July 29, 2005 (http://www.ers.usda.gov/ Briefing/incomepovertywelfare/ruralpoverty/)

Evans, G.W. 2004. "The Environment of Childhood Poverty.' American Psychologist 59:77-92.

Fisher, M. 2005. "On the Empirical Finding of a Higher Risk of Poverty in Rural Areas: Is Rural Residence Endogenous to Poverty?" Journal of Agricultural and Resource Economics 30:185-99.

Fisher, M.G. and B.A. Weber. 2004. "Does Economic Vulnerability Depend on Place of Residence? Asset Poverty across Metropolitan and Nonmetropolitan Areas." The Review of Regional Studies 34:137-55.

Fitchen, J.M. 1991. Endangered Spaces, Enduring Places. Boulder, CO: Westview Press.

Fossett, M.A. and T. Seibert. 1997. Long Time Coming: Racial Inequality in the Nonmetropolitan South, 1940-1990. Boulder, CO: Westview Press.

Foulkes, M. and K.B. Newbold. 2005. "Geographic Mobility and Residential Stability in Impoverished Rural Illinois Places.” Environment and Planning A 37:845-60.

Friedman, S. and D.T. Lichter. 1998. "Spatial Inequality and Poverty among American Children." Population Research and Policy Review 17:91-109.

Frey, W.H. and R. Farley. 1996. "Latino, Asian, and Black Segregation in U.S. Metropolitan Areas: Are Multiethnic Metros Different?" Demography 33:35-50.

Fuguitt, G.V., T.B. Heaton, and D.T. Lichter. 1988. "Monitoring the Metropolitanization Process." Demography 25:115-28.

Furstenberg, F.F. and M.E. Hughes. 1997. "The Influence of Neighborhoods on Children's Development: A Theoretical Perspective and a Research Agenda." Pp. 23-47 in Neighborhood Poverty: Context and Consequences for Children, edited by J. Brooks-Gunn, G. Duncan, and J.L. Aber. New York: Russell Sage Foundation.

Ginther, D., R. Haveman, and B. Wolfe. 2000. "Neighborhood Attributes as Determinants of Children's Outcomes: How Robust are the Relationships?" Journal of Human Resources 35:603-42.

Gundersen, C. 2006. "Are the Effects of the Macroeconomy and Social Policies on Poverty Different in Nonmetro Areas in the United States?" Rural Sociology 71:545-72.

Iceland, J. 2003. "Why Poverty Remains High: The Role of Income Growth, Economic Inequality, and Changes in Family Structure, 1949-1999."' Demography 40:499-519.

Jargowsky, P.A. 2003. "Stunning Progress, Hidden Problems: The Dramatic Decline of Concentrated Poverty in the 1990s." Living Cities Series. Washington DC: Brookings Institution. 
Jargowsky, P.A. and R. Yang R. 2006. “The 'Underclass' Revisited: A Social Problem in Decline." Journal of Urban Affairs 28:55-70.

Jensen, L. 2006a. "At the Razor's Edge: Building Hope for America's Rural Poor." Rural Realities 1(1):1-8.

. 2006b. New Immigrant Settlements in Rural America: Problems, Prospects and Policies. Reports on Rural America, 1(3). Carsey Institute: Durham, NH.

Jensen, L., S.J. Goetz, and H. Swaminathan. 2006. "Changing Fortunes: Poverty in Rural America." Pp. 131-52 in Population Change and Rural Society, edited by W.A. Kandel and D.L. Brown. Dordrecht, The Netherlands: Springer.

Jensen, L., D.K. McLaughlin, and T. Slack. 2003. "Rural Poverty: The Persisting Challenge." Pp. 118-31 in Challenges for Rural America in the Twenty-First Century, edited by D.L. Brown and L.E. Swanson. University Park, PA: Penn State University Press.

Johnson, K.M. 2005. “Persistent Child Poverty in the United States, 1970 to 2000.” Poster prepared by the Population Reference Bureau. Washington, D.C.

Johnson, K.M. and G.V. Fuguitt. 2000. "Continuity and Change in Rural Migration Patterns, 1950 1995." Rural Sociology 65:27-49.

Jollife, D. 2004. Rural Poverty at a Glance. Rural Development Research Report No. RDRR100. Washington, DC: Economic Research Service, USDA.

Kingsley, G.T. and K.L.S. Pettit. 2003. "Concentrated Poverty: A Change in Course." Neighborhood Change in Urban America Series, No. 2., May. Washington, DC: The Urban Institute.

Lee, M.A. and J. Singelmann. 2005. "Welfare Reform Amidst Chronic Poverty in the Mississippi Delta." Pp. 381-403 in Population Change and Rural Society, edited by W.A. Kandel and D.L. Brown. Dordrecht, The Netherlands: Springer.

Lichter, D.T. 1985. "Racial Concentration and Segregation Across U.S. Counties, 1950 1980." Demography 22:603-9.

Lichter, D.T. and L. Jensen. 2002. "Rural America in Transition: Poverty and Welfare at the Turn of the Twenty-First Century." Pp. 113-46 in Rural Dimensions of Welfare Reform, edited by B.A. Weber, G.J. Duncan, and L.A. Whitener. Kalamazoo, MI: W.E. Upjohn Institute for Employment Research.

Lichter, D.T. and K.M. Johnson. 2006. "Emerging Rural Settlement Patterns and the Geographic Redistribution of America's New Immigrants." Rural Sociology 71:109-31.

Lichter, D.T. and D.K. McLaughlin. 1995. "Changing Economic Opportunities, Family Structure, and Poverty in Rural Areas." Rural Sociology 60:688-706.

Lichter, D.T., D. Parisi, S.M. Grice, and M. Taquino. 2007. "Municipal Underbounding: Annexation and Racial Exclusion in Small Southern Towns." Rural Sociology 72:47-68.

Lichter, D.T., Z.C. Qian, and M.L. Crowley. 2005. "Child Poverty among Racial Minorities and Immigrants: Explaining Trends and Differentials." Social Science Quarterly $86: 1037-59$.

Lobao, L. 2004. "Continuity and Change in Place Stratification: Spatial Inequality and Middle-Range Territorial Units." Rural Sociology 69:1-30.

Long, L. and A. Nucci. 1997. "The 'Clean Break' Revisited: Is US Population Again Deconcentrating?"' Environment and Planning 29:1355-66.

Lyson, T.A. and W.W. Falk. 1991. Forgotten Places: Uneven Development and Loss of Opportunity in Rural America. Lawrence, KS: University of Kansas Press.

Massey, D.S. and N. Denton. 1993. American Apartheid: Segregation and the Making of the Underclass. Cambridge, MA: Harvard University Press.

Massey, D.S., M.J. White, and V.C. Phua. 1996. "The Dimensions of Segregation Revisited." Sociological Methods and Research 25:172-206.

McLanahan, S. 2005. "Diverging Destinies: How Children are Faring Under the Second Demographic Transition." Demography 41:607-27.

Miller, K. and B. Weber. 2003. Persistent Poverty Across the Rural-Urban Continuum. WP 03-01. Columbia, MO: Rural Policy Research Center, University of Missouri. 
Neumark, D. and W. Wascher. 2001. "Using the EITC to Help Poor Families: New Evidence and a Comparison with the Minimum Wage." National Tax Journal 54:281-317.

Nord, M., A.E. Luloff, and L. Jensen. 1995. "Migration and the Spatial Concentration of Poverty." Rural Sociology 60:399-415.

O'Hare, W.P. and K.M. Johnson. 2004. "Child Poverty in Rural America." Reports on America 4(March):1-19.

Otterstrom, S.M. and J.M. Shumway. 2003. "Deserts and Oases: The Continuing Concentration of Population in the American Mountain West." Journal of Rural Studies 19:445-62.

Parisi, D., S.M. Grice, M. Taquino, and D. Gill. 2005. "Community Concentration and its Consequences on Nonmetropolitan County Persistence of Poverty in Mississippi." Sociological Spectrum 25:469-83.

Partridge, M.D. and D.S. Rickman. 2005. "High Poverty Nonmetropolitan Counties in the United States: Can Economic Development Help?" International Regional Science Review 28:415-40.

Pollard, K.M. 2004. “A 'New Diversity': Race and Ethnicity in the Appalachian Region.', Series on Demographic and Economic Change in Appalachia. Washington DC: Population Reference Bureau and Appalachian Regional Commission.

Rank, M.R. 2004. One Nation, Underprivileged: Why American Poverty Affects Us All. New York: Oxford University Press.

Rainwater, L. and T.M. Smeeding. 2003. Poor Kids in a Rich Country: America's Children in Comparative Perspective. New York: Russell Sage Foundation.

Saenz, R. 1997. "Ethnic Concentration and Chicano Poverty: A Comparative Approach.' Social Science Research 26:205-28.

Saenz, R. and J.K. Thomas. 1991. "Minority Population in Nonmetropolitan Texas." Rural Sociology 56:204-23.

Schafft, K.A. 2006. "Poverty, Residential Mobility, and Student Transiency with a Rural New York School District.”' Rural Sociology 71:212-31.

Snyder, A.R. and D.K. McLaughlin. 2004. "Female-Headed Families and Poverty in Rural America." Rural Sociology 69:127-49.

Snyder, A.R., D.K. McLaughlin, and J. Findeis. 2006. "Household Composition and Poverty among Female-Headed Households with Children: Differences by Race and Residence." Rural Sociology 71:597-624.

Tickamyer, A.R. and C.M. Duncan. 1990. "Poverty and Opportunity Structure in Rural America." Annual Review of Sociology 16:67-86.

Tomaskovic-Devey, D. and V.J. Roscigno. 1996. "Racial Economic Subordination and White Gain in the U.S. South.” American Sociological Review 61:565-89.

U.S. Census Bureau. 2006. POV40. Age, Sex, Household Relationship, by Region and ResidenceRatio of Income to Poverty Level. Retrieved September 9, 2006 (http://pubdb3.census. gov/macro/032006/pov/new40_004.htm).

Voss, P., D.D. Long, R.B. Hammer, and S. Friedman. 2006. “County Child Poverty Rates in the U.S.: A Spatial Regression Approach." Population Research and Policy Review 25:369-91.

Weber, B.A., G.J. Duncan, and L.A. Whitener. 2002. Rural Dimensions of Welfare Reform. Kalamazoo, MI: W.E. Upjohn Institute for Employment Research.

Weber, B.A., L. Jensen, K. Miller, J.M. Mosley, and M. Fisher. 2005. "A Critical Review of Rural Poverty Literature: Is There Truly a Rural Effect?” International Regional Science Review 28:381-414.

Weinberg, D.H. 1987. "Rural Pockets of Poverty.” Rural Sociology 52:398-408.

Wilkes, R. and J. Iceland. 2004. "Hypersegregation in the Twenty-First Century." Demography 41:23-36. 